\title{
THE POWER OF PODCASTING: PERSPECTIVES ON PEDAGOGY
}

Stephanie Maher Palenque

Grand Canyon University

\section{ABSTRACT}

This paper examines the origins of podcasting, the value of podcasting in higher education, the influence of podcasting on student learning and engagement, and possibilities for future development in this area. The writings of other researchers in this field, such as Perkins (1999), Mayas, and de Freitas (2004), who postulate that podcasting complements a Constructivist approach in the classroom, provide much of the research foundation for this paper. The connection between podcasting information in multiple singleconcept blocks and the traditional chunking of classroom material draws on Simonson's research. This notion has roots in the research connected with learning and long term memory (Newell, 1990; West \& Grigolini, 2010). Podcasting in higher education is a modern-day manifestation of the theories of eminent scholars such as Dewey, Piaget and Vygotsky (Ng'ambi \& Lombe, 2012). It supports active, social and creative aspects of learning, and provides opportunities for reflection, self-paced and independent learning.

Keywords: podcasts, podcasting, online teaching, dialogue, feedback, chunking

The benefits of asynchronous interactive educational podcasting between instructors and students are many. The unique marriage of practical benefits such as usability and ease of access, with educational benefits such as the opportunity to offer single-concept-themed lectures on-the-go, condensed review or reflection on lecture material, personalized narrative feedback, and gentle guidance to the student should not be overlooked. This paper focuses on two of the most beneficial ways to use podcasts in the college classroom: as short, single-concept lectures, overviews of focused material, reviews, and narrative audio feedback to students.

\section{BRIEF OVERVIEW OF PODCASTING}

Podcasts (the term is a hybrid of 'iPod' and 'broadcast'), which are audio broadcasts distributed via the Internet, are not a new concept. Podcasting has existed at least since the audio tutorial movement and the Sony Walkman (Simonson, n.d.). Even though it is not exactly a new technology, all of the benefits podcasting may offer when integrated into higher learning and the online classroom are still being discovered. Podcasters create digital media files and upload them to their websites where users can listen to them directly or download them to an MP3 player or other media listening device (Gaden, 2010). Some qualities of effective podcasts include that they represent a single idea that can be explained verbally, they are part of a series with each single event related to others, they are available in an electronic format that is easily played, often as an MP3 file, they are stored on a website or other Internet location for easy access, and are current and changed or updated frequently (Simonson, n.d.).

\section{EDUCATIONAL USES OF PODCASTING}

Educators have long been intrigued by the possibilities that this technology holds. The use of podcasts in the online classroom has great potential not only because podcasts help differentiate learning (Cooper, 2008) and provide additional support to students who have specific learning needs (Powell \& Robson, 2014) but also because they foster a 
sense of inclusivity and belonging to the learning community (Van Zanten, Somogy, \& Curro, 2012). Harris and Park (2007) suggest that there are multiple characteristics of educational podcasting in institutions of higher learning including Teachingdriven podcasting, Service-driven podcasting, Marketing-driven podcasting, and Technologydriven podcasting (Harris \& Park, 2008). For the purpose of this paper, the focus is educational podcasting from an instructor's perspective. While there are many ways that an instructor may use podcasting in the online classroom, this paper focuses on two main uses: delivery of theme-based, short podcast lectures, and delivery of individual custom feedback from instructor to student.

While the technology exists to capture an entire lecture by podcast, this is not seen as a best practice in education. According to Simonson, recording of a lecture is a poor example of a podcast (n.d.). Rather, it is best to "chunk" the class material into five or six single concept blocks, each as a separate learning object (Simonson, n.d.). Seasoned educators already "chunk" or break up their class session into related or themed topics due to the benefits connected with learning and long-term memory (Newell, 1990; West \& Grigolini, 2010). These single concepts may be recorded as podcasts and can be effective in educational settings, especially if they are supplemented with related examples and recorded in a proper location without the distraction of background noises. Specific benefits mentioned by students in a recent study (Hill, Nelson, France, \& Woodland, 2012) include the opportunity to access podcasts at home or on the go, engage with the content by making written notes, and the ability to repeat podcasts in order to retrieve information, clarify issues, and highlight knowledge gaps. These opportunities help students manage their own education and encourage student autonomy.

Another way of promoting student autonomy in classes is delivery of short, customized narrative audio feedback files for students. The importance of effective feedback that is delivered to the student in a palatable manner cannot be understated. As cited in Cooper (2008), good quality feedback is paramount in the pursuit of lifelong learning and is especially valuable in helping learners internalize standards and actively respond to areas for individual enhancement thus improving the quality of assessed work prior to its submission.
What constitutes effective feedback is a key point in education research, and there are many theories in this area. Educators must recognize that not all learners will read their written feedback, and those who do may not easily decode and translate the feedback received, since feedback must go beyond mere transmission of information (Cooper, 2008, p. 154). However, studies of student perception of effective feedback regularly report the same themes: student individuation, gentle guidance, ongoing coaching and timeliness (Getzlaf, Perry, Toffner, Lamarche \& Edwards, 2009). These areas can be addressed in an effective manner by delivering instructor-to-student feedback through audio files.

In Cooper's study (2008), a positive theme emerged in the interviews with students who received feedback in the form of audio files. Students indicated that the level of detail and the personal and unique nature of the audio feedback made the context of the comments very clear. This was considered to be more effective than written responses, which could be difficult to decode. Integrating this audio feedback alongside learning and teaching materials delivered as podcasts created an undeniable synergy and consistency to which students could relate. The informal style of delivery associated with weekly podcasts was consistent and it became clear that students could relate to the delivery style of the instructor (Cooper, 2008).

Until recently, audio feedback for students has been beneficial from a student engagement standpoint, but has proven to be more timeintensive for instructors. According to Mathieson (2012) audio feedback took twice as long as textonly feedback (as cited in Portolese Dias \& Trumpy, 2014). However, with the advent of new built-in technologies in learning management systems such as Canvas (open source), the demand on instructors' time has decreased. A study at West Virginia University found that audio feedback took instructors an average of 3.81 minutes per student, as opposed to written feedback which took instructors an average of 13.43 minutes per assignment to prepare (Ice et al, 2007).

\section{INFLUENCE OF PODCASTING ON STUDENT LEARNING AND ENGAGEMENT}

Technology, podcasts in particular, has been praised for supporting autonomous learning in students (as stated in Hill, Nelson, France 
\& Woodland, 2012). The use of podcasts in the classroom complements a Constructivist approach, which holds its roots in the theories of eminent scholars such as Dewey, Piaget and Vygotsky (Ng'ambi \& Lombe, 2012). According to Perkins (1999), Constructivism is a composite of different views incorporating active, social and creative aspects of learning. Mayes and de Freitas (2004) consider learning as the realization of understanding through active discovery, dialogue and collaboration. Furthermore, they argue Constructivism is concerned with the internalization of knowledge and skills, their integration into existing structures and the effect of support on their emergence. Effective learning can be applied to different contexts, expressed in new ways, including the use of technologies which provide opportunity for reflection, self-paced and independent learning.

Instructors often question whether students read feedback returned on their papers. Lunt and Curran (2010) report that students are 10 times more likely to open audio files when compared to written feedback. A combination of both written and audio feedback may be a winning combination. Merry and Orsmond (2008) report that students responded positively to a combination of both written and audio feedback. The participants of the study judged the audio feedback as providing more depth, perhaps because the feedback provided suggestion strategies for solving problems, rather than simply stating what the problems were (Merry \& Orsmond, 2008).

\section{THE FUTURE OF PODCASTING IN ASYNCHRONOUS CLASSROOMS}

The future of podcasting in educational settings is strong. There will be new technologies built upon existing ones in order to capitalize on this tool. According to Chester, Buntine, Hammond, and Atkinson, (2011) chaptering podcasts would enable easy searching and permit students to find specific sections more efficiently. Given that one of the primary reasons for using podcasts appears to be to review specific, difficult material, facilitating this process would be a worthwhile goal (p. 245). For the same reasons, indexing podcasts with hyperlinks for better navigation would also be beneficial for the end user.

\section{CONCLUSION}

The central question when evaluating any technology and considering those tools for use in the classroom must focus on student learning: "In what ways does the use of podcasting have the potential to positively impact student learning (CollierReed, Case, \& Stott, 2013)? While podcasting in the college classroom may be innovative and technologically advanced, the final result must have a positive effect on the student experience, enhancing student learning. As Jones (2010) notes, "Podcasting offers the potential for exploring the aural mode of communication in service of the written." This paper demonstrates just a few select ways that this classroom tool might benefit learners.

\section{References}

Chester, A., Buntine, A., Hammond, K., \& Atkinson, L. (2011). Podcasting in education: Student attitudes, behaviour and self-efficacy. Educational Technology \& Society, 14(2), 236247.

Collier-Reed, B. I., Case, J. M., \& Stott, A. (2013). The influence of podcasting on student learning: a case study across two courses. European Journal of Engineering Education, 38(3), 329-339. http://dx.doi.org/10.1080/03043797.2013.786026

Cooper, S. (2008). Delivering student feedback in higher education: The role of podcasting. Journal of Music, Technology and Education, 1(2 \& 3). http://dx.doi.org/10.1386/jmte.1.2 and $3.153 / 1$

Gaden, G. (2010, September 1). Podcasting: Thinking about new opportunities for pedagogy and activism. thirdspace.

Getzlaf, B., Perry, B., Toffner, G., Lamarche, K., \& Edwards, M. (2009). Effective Instructor Feedback: Perceptions of Online Graduate Students. Journal Of Educators Online, 6(2),

Harris, H., \& Park, S. (2008). Educational usages of podcasting. British Journal of Educational Technology, 39(3), 548-551. http://dx.doi.org/10.1111/j.1467-8535.2007.00788.x

Hill, J., Nelson, A., France, D., \& Woodland, W. (2012). Integrating podcast technology effectively into student learning: A reflexive examination. Journal of Geography in Higher Education, 36(3), 437-454. http://dx.doi.org/10.1080/0309826 5.2011 .641171

Ice, P., Curtis, R., Phillips, P., \& Wells, J. (July 2007). Asynchronous audio feedback to enhance teaching presence and students' sense of community, Sloan C Conference proceedings, 1, (2).

Jones, L. A. (2010). Podcasting and performativity: Multimodal invention in an advanced writing class. Composition Studies, 38(2), 75-91. 
Lunt, T. \& Curran, J. (2010) Are you listening, please? The advantages of electronic audio feedback compared to written feedback. Assessment \& Evaluation in Higher Education, 35, (7), 759-769.

Mayes, T. \& de Freitas, S. (2004). JISC e-learning models desk study: Stage 2:Review of e-learning theories, frameworks and models. Retrieved from the Joint Information Steering Committee website: http://www.jisc.ac.uk/uploaded_ documents/Stage\%202\%20Learning\%20Models\%20 \%28\%Version\%201\%29.pdf

Merry, S., \& Orsmond, P. April 2008. Student attitudes to usage of academic feedback provided via audio files. Bioscience Education Journal. 11. 23-26. DOI 10.3108.

Newell, A. (1990) Unified theories of cognition. Harvard University Press, Cambridge.

Ng'ambi, D., \& Lombe, A. (2012). Using podcasting to facilitate student learning: A constructivist perspective. Educational Technology \& Society, 15(4), 181-192.

Perkins, D. (1999). The many faces of constructivism. Educational Leadership, 57(3), 6-11.

Portolese Dias, L., \& Trumpy, R. (2014). Online Instructor's Use of Audio Feedback to Increase Social Presence and Student Satisfaction. Journal of Educators Online, 11(2),

Powell, L., \& Robson, F. (2014). Learner-generated podcasts: a useful approach to assessment? Innovations in Education and Teaching International, 51(3), 326-337. http://dx.doi.org/10.108 0/14703297.2013.796710

Simonson, M. (n.d.). Podcasting ...or "seeds floated down from the sky”. Distance Learning, 12(1), 15-16.

VanZanten, R., Somogyi, S., \& Curro, G. (2012). Purpose and preference in educational podcasting. British Journal of Educational Technology, 43(1), 130-138. http://dx.doi. org/10.111/j.1467-8535.2010.01153.x

West, B. J., \& Grigolini, P. (2010). Chipping away at memory. Biological Cybernetics, 103(2), 167-174. doi:10.1007/s00422010-0394-6

\section{Author Biography}

Stephanie Maher Palenque is an assistant professor, researcher and writer in the College of Humanities and Social Sciences at Grand Canyon University. Her scholarship focuses on writing education, online instruction and faith integration in the classroom. She has presented her work in these areas at professional conferences and as a contributor to academic and peer-reviewed journals. Palenque won a Distinguished Faculty Scholar Award from GCU in 2015 and was the co-recipient of a scholarly engagement grant in which she studied plagiarism from a faculty perspective in the online modality. She is currently working on the dissertation for her $\mathrm{PhD}$ in Psychology with an emphasis in Cognition and Instruction. 